\title{
HOME QUARANTINE OR HOME ISOLATION DURING THE COVID-19 PANDEMIC AS A Deprivation of Liberty UNDER Polish
}

\section{LAW}

Accepted

10. 05.2021

Revised

18. 05.2021

Published

29. 10. 2021

Keywords

preventive

detention,

personal

liberty,

principle of

proportionality,

community-

wide

containment,

confinement

\section{Tomasz Sroka}

Jagiellonian University, Faculty of Law and Administration, Department of Bioethics and Medical Law, Krakow, Poland.

E-mail: tomasz.sroka@uj.edu.pl

CORRESPONDING AUTHOR

tomasz.sroka@uj.edu.pl

Abstract Combating the COVID-19 pandemic requires that States should take many measures, which may also substantially interfere with the rights or freedoms of individuals. One commonly used mechanism to counter the spread of the SARS-CoV-2 virus is home quarantine or home isolation. Bearing in mind the guidelines arising from ECHR case-law, the article assesses whether home quarantine or home isolation applied under Polish law constitutes a deprivation of liberty. Taking into consideration the manner and conditions of these isolation measures and the possibility of using coercive measures, home quarantine or home isolation under Polish law constitutes deprivation of liberty within the meaning of Article 5(1)(e) of the ECHR. Then attention is drawn to selected consequences arising from this classification. In particular, it is emphasized that they cannot be imposed by a decision of the legislator, but only as a result of an act of law enforcement by sanitary authorities or courts. 


\section{$1 \quad$ Introduction}

The epidemic of the SARS-CoV-2 virus and COVID-19 disease has drawn renewed attention to the State's responsibilities to adequately protect the interests of individuals and society, particularly in protecting life and health. Among the positive obligations of the State is the necessity to take measures that will guarantee an adequate level of protection of human life and health in connection with known, foreseen or foreseeable threats to these values. These positive obligations of the State also implies the need to protect individuals against threats to life and health arising from the possibility of transmitting infectious and fatal diseases and infections, such as the SARS-CoV-2 virus (Spadaro, 2020).

Combating an epidemic or pandemic requires States to take appropriate measures to ensure adequate health protection for those already infected and to protect other members of society from becoming infected and endangering their lives and health. Since there are few effective tools available to prevent the spread of infection, States must impose restrictions on the rights and freedoms of individuals in order to protect the public health of society. An example of such restrictions is the obligation to undergo quarantine due to the actual or suspected infection with a virus. Quarantine is considered to be one of the oldest, but also currently one of the most effective tools to prevent the spread of infections and infectious diseases (WilderSmith, 2020: 1-2). Isolation is the confinement of a person who has been diagnosed with an infectious disease, and quarantine is the confinement of a person suspected of being infected who may have come into contact with a particular pathogen.

This example illustrates that the policy of preventing the spread of infections and infectious diseases is built on the conflict between the need to protect public health, i.e. the life and health of all members of society, and the need to protect the rights and freedoms of individuals, who should be subjected to various types of preventive mechanisms. On the one hand, the State's obligation includes taking measures aimed at preventing the spread of infections or contagious diseases, as well as enabling individuals to have access to a health care system where they can receive medical assistance appropriate to the threat. On the other hand, the State still has the duty to protect other rights and freedoms of individuals, the restriction of which may be necessary for the proper management of the risks associated with an outbreak of a communicable disease. It is the task of the public authority to resolve this conflict 
appropriately and to limit the rights and freedoms of individuals in a proportionate manner in order to protect the public health of society (Meier, Evans \& Phelan, 2020; Sroka, 2020: 77-78).

The actions taken by States in combating the COVID-19 outbreak led to restrictions on a wide variety of individual freedoms or rights, such as the freedom of movement, the freedom of assembly, the freedom to conduct business, the right to protect family life, and the right to education. This catalogue of restrictions also includes measures which led to the restriction or even the temporary deprivation of personal liberty of individuals resulting from quarantine (Spadaro, 2020: 3-4). These examples of the deprivation of liberty may be named preventive detention, because individuals were deprived of their individual liberty in order to protect the life and health of other members of the public in the future. Governmental imposition of these drastic restrictions on the rights or freedoms of individuals during a nationwide (worldwide) epidemic (pandemic) appears to be an adequate solution given the nature, extent and character of the threat to public health and the type of protected values (human life and health), (Katzenmeier, 2020: 3). Moreover, the possibility for the State to resort to such measures, which may even lead to the preventive deprivation of personal liberty, seems to be a valid option in the case of new pathogens which have the potential to develop into a pandemic (Ashworth \& Zender, 2014: 202; Wiley, 2018: 256). The SARS-CoV-2 virus certainly belongs to this group.

Importantly, the qualification of quarantine or isolation, in particular home quarantine or home isolation, as a deprivation of liberty, cannot be made in the abstract. It is necessary to distinguish a deprivation of liberty within the meaning of Article 5 ECHR from a mere restriction on freedom of movement within the meaning of Article 2 of Protocol No 4 ECHR. Although quarantine or isolation constitutes a restriction of personal liberty in the broad sense, whether it should be classified merely as a restriction on freedom of movement or as a deprivation of liberty will depend on an assessment of the form of such measures under domestic law, their duration, effects and implementation (Trechsel, 1993: 285; Schabas, 2015: 226). The same restriction of personal liberty may in one instance constitute a deprivation of liberty, and in another constitute a mere restriction on the freedom of movement. This assessment must always be made in concreto (Sroka, 2021: 46). In the following part of this paper, I will present the criteria for distinguishing deprivation of liberty and explain why, under Polish law, home quarantine or home 
isolation constitutes a deprivation of liberty, and not merely a restriction on the freedom of movement.

\section{Deprivation of liberty in order to prevent spreading infectious disease}

Article 5(1)(e) of the European Convention on Human Rights permits depriving a person of liberty in order to prevent the spread of a communicable disease. In the case of certain types of disease or infection, including the SARS-CoV-2 virus, compulsory isolation, quarantine or hospitalization, even in the form of preventive detention, appear to be the best measures which the State can take to control the infection and protect the whole population (Elias, 2016: 136). As the ECtHR pointed out: „the essential criteria when assessing the 'lawfulness' of the detention of a person "for the prevention of the spreading of infectious diseases" are whether the spreading of the infectious disease is dangerous to public health or safety, and whether detention of the person infected is the last resort in order to prevent the spreading of the disease, because less severe measures have been considered and found to be insufficient to safeguard the public interest" (Enhorn v. Sweden, case no.: 56529/00, ECLI:CE:ECHR:2005:0125JUD005652900, §44).

The basis of Article 5(1)(e) ECHR concerns the admissibility of the deprivation of liberty, not of persons suffering from an infectious disease, but of persons not presently infected, in order to prevent them from spreading an infectious disease. The danger of spreading an infectious disease can also be generated by the behaviour of people who are not yet infectious. In the case of infectious diseases, the deprivation of liberty may therefore apply not only to persons in respect of whom the disease has already been diagnosed, but also to persons in respect of whom it is feared that they have had contact with the infectious disease, may have become infected and may spread the infection. As a consequence, public authorities often use two forms of interference in the sphere of personal freedom of individuals, related to preventing the spread of infectious diseases: isolation and quarantine.

Both isolation and quarantine constitute intrusions into the sphere of individual liberty and their application may lead to a conflict between the adequate protection of the interests of society on the one side and the rights and freedoms of individuals on the other (Meier, Evans \& Phelan, 2020: 227). Unless an exceptional mechanism of temporary derogation of the standard of protection of human rights has been 
used, restrictions on the rights and freedoms of individuals, including during the COVID-19 pandemic, must meet the requirements resulting from the ECHR. This means that any proposed restrictions must be introduced in accordance with procedures proscribed by law, for a legitimate purpose, applying the principles of necessity and proportionality (Spadaro, 2020: 4; Sroka, 2020: 80). Moreover, if measures involving isolation or quarantine result in the deprivation of liberty, further substantive and procedural requirements under Article 5 ECHR must be complied with. The main purpose of these guarantees is to protect individuals against arbitrary deprivation of liberty.

Taking into account the standard of protection of human rights, no significant problems arise when a person infected or suspected of being infected with the SARS-CoV-2 virus makes a conscious and voluntary decision to remain in a particular place for a specified period of time until the danger of the spread of the infectious disease has ceased. In such a case, there are no grounds for qualifying such voluntary isolation or quarantine as a deprivation of liberty within the meaning of Article 5(1) of the ECHR. When isolation or quarantine is carried out in an institutionally adapted place (hospital or isolation centre), where the individual is obliged to remain even without consent, with the possibility of coercive measures being taken to prevent the person from leaving that place of stay, that situation constitutes a deprivation of liberty within the meaning of Article 5(1) of the ECHR. This situation is similar to the forced stay of a patient in a psychiatric hospital, except that the reason for hospitalization is not a mental disorder, but instead a suspicion of the existence or diagnosis of an infectious disease.

In the light of the case-law of the ECtHR, there is no doubt that the involuntary confinement of a patient in a psychiatric hospital constitutes a deprivation of liberty within the meaning of Article 5(1) of the ECHR. The ECtHR points out that: "the notion of deprivation of liberty comprises both an objective element, namely a person's confinement in a restricted space for a significant length of time, and a subjective element, namely the person's lack of valid consent to the confinement". ${ }^{1}$

\footnotetext{
1 Akopyan v. Ukraine, case no.: 12317/06, ECLI:CE:ECHR:2014:0605JUD001231706, \67. See also: Storck v. Germany, case no.: 61603/00, ECLI:CE:ECHR:2005:0616JUD006160300, § 74; Shtukaturov v. Russia, case no.: 44009/05, ECLI:CE:ECHR:2010:0304JUD004400905, \106; Stanev v. Bulgaria, case no.: 36760/06, ECLI:CE:ECHR:2012:0117JUD003676006, \$ 117; D.D. v. Lithuania, case no.: 13469/06, ECLI:CE:ECHR:2012:0214JUD001346906, \ 145; M. v. Ukraine, case no.: 2452/04, ECLI:CE:ECHR:2012:0419JUD000245204, \69; Kedzior v. Poland, case no.: 45026/07, ECLI:CE:ECHR:2012:1016JUD004502607, \ 55; Mihailovs v. Latvia, case no.: 35939/10,
} 
In the case of quarantine or isolation in a hospital or isolation centre (in order to prevent the spread of a contagious disease), as in the case of confinement in a psychiatric hospital, the objective and subjective criteria of deprivation of liberty also would be met. Consequently, such forcible confinement in an infectious hospital or isolation facility should be qualified as a deprivation of liberty under Article 5(1)(e) of the ECHR, and the person deprived of liberty in these situations should be afforded all procedural guarantees stemming from Article 5 of the ECHR.

The most difficult situation to assess, however, is the forced home quarantine or home isolation on individuals, which is extremely common in many countries during the COVID-19 pandemic. A person, because of infection or suspected infection with the SARS-CoV-2 virus, is required to remain at home for several days, sometimes until a negative test result for the SARS-CoV-2 virus is obtained. This obligation is imposed by law in the event of certain factual circumstances (e. g. crossing a state border) or by decision of the sanitary authorities. The question arises, however, whether such an obligation to remain at home for a specified period of time, under quarantine or isolation, constitutes a deprivation of liberty within the meaning of Article 5(1) of the ECHR.

\section{Criteria for determining deprivation of liberty}

The ECtHR has repeatedly stated that "in order to determine whether someone has been 'deprived of his liberty' within the meaning of Article 5, the starting-point must be his concrete situation, and account must be taken of a whole range of criteria such as the type, duration, effects and manner of implementation of the measure in question. The difference between deprivation of and restriction upon liberty is merely one of degree or intensity, and not one of nature or substance". ${ }^{2}$ At the same time, in order for a particular situation to be classified as deprivation of liberty, it is

\footnotetext{
ECLI:CE:ECHR:2013:0122JUD003593910, \128; Atudorei v. Romania, case no.: 50131/08, ECLI:CE:ECHR:2014:0916JUD005013108, § 128.

2 Amuur v. France, case no.: 19776/92, ECLI:CE:ECHR:1996:0625JUD001977692, @ 42. See also Engel and others v. the Netherlands, case no.: 5100/71, 5101/71, 5102/71, 5354/72 and 5370/72,

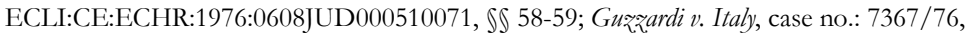

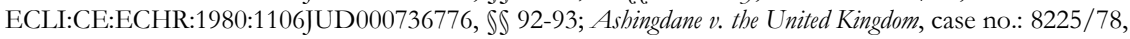
ECLI:CE:ECHR:1985:0528JUD000822578, \ 41; H.L. v. the United Kingdom, case no.: 45508/99, ECLI:CE:ECHR:2004:1005JUD004550899, \ 89; Storck v. Germany, 2000, \ 71; Shtukaturov v. Russia, 2005, \ 105; Stanev v. Bulgaria, 2006, \ 115; D.D. v. Lithuania, 2006, \144; Creangă v. Romania, case no.: 29226/03, ECLI:CE:ECHR:2012:0223JUD002922603, \ 91; Kędzior v. Poland, 2007, \54; Mihailovs v. Latvia, 2010, \ 128; Atudorei v. Romania, 2008, \127.
} 
not necessary for the individual to remain "in a closed" place (room, building). The essential criteria are the type and nature of the restrictions on the exercise of personal liberty. " 'A person can be 'deprived of his liberty', indeed detained in the fullest and most complete sense of the word, even though his departure from the place of detention is not prevented by a locked door or by any other physical barrier". ${ }^{4}$

Based on an analysis of the ECtHR case-law, it may be concluded that in order to determine whether a particular situation constitutes a deprivation of liberty within the meaning of Article 5(1) of the ECHR, it is necessary to take into account several criteria (Sroka, 2021: 78-81). Firstly, as mentioned, the essence of deprivation of liberty is the imposition on the individual of an obligation to remain in a specific, limited space, without the possibility of freely shaping the place of stay (residence). This obligation is not limited to staying in a place that is institutionally prepared to provide 24-hour care and supervision for individuals (e.g. hospitals, arrests, prisons), but may also include the obligation to stay in other specified places, not excluding the home. The ECtHR has, for example, qualified house arrest as a deprivation of liberty. ${ }^{5}$

Secondly, the essence of deprivation of liberty is the existence of a legal and factual possibility to compel an individual to remain in a specified location in accordance with the obligation imposed by law. This means that the staff of a particular place or public officers must have the legal and actual authority to take coercive measures to prevent an individual from leaving a particular place, or to force an individual to return if he or she leaves. It is not necessary that coercive measures should be used, in particular the physical "confinement" of the individual in a particular place. The existence of the possibility, including the threat, of the use of direct coercion shall be sufficient. The element of coercion may also be the threat of criminal prosecution, in order to force an individual to stay in a certain place. ${ }^{6}$

\footnotetext{
${ }^{3}$ H.L. v. the United Kingdom, 1999, , 92.

${ }^{4}$ JE v. DE, case no.: FD06P01393, [2006] EWHC 3459 (Fam), \ 118.

${ }_{5}^{5}$ Mancini v. Italy, case no.: 44955/98, ECLI:CE:ECHR:2001:0802JUD004495598, \$17; Lavents v. Latvia, case no.: 58442/00, ECLI:CE:ECHR:2002:1128JUD005844200, § 63; Vachev v. Bulgaria, case no.: 42987/98, ECLI:CE:ECHR:2004:0708JUD004298798, § 64; Nikolova v. Bulgaria (no 2), case no.: 40896/98, ECLI:CE:ECHR:2004:0930JUD004089698, \ 60; Dacosta Silva v. Spain, case no.: 69966/01, ECLI:CE:ECHR:2006:1102JUD006996601, \44; Ninescu v. the Republic of Moldova, case no.: 47306/07, ECLI:CE:ECHR:2014:0715JUD004730607, \53; Delijorgji v. Albania, case no.: 6858/11, ECLI:CE:ECHR:2015:0428JUD000685811, \ 75; Buqadji v. the Republic of Moldova, case no.: 23755/07, ECLI:CE:ECHR:2016:0705JUD002375507, § 104.

${ }^{6}$ Gillan and Quinton v. the United Kingdom, case no.: 4158/05, ECLI:CE:ECHR:2010:0112JUD000415805, \57; Shimovolos v. Russia, case no.: 30194/09, ECLI:CE:ECHR:2011:0621JUD003019409, 』50.
} 
Thirdly, the state of deprivation of liberty requires the existence of mechanisms to control whether the individual fulfils the obligation to stay in the designated place. This control can involve a range of different activities and solutions, from personal observation to various types of technical solutions. The ECtHR noted, for example, that the deprivation of liberty of a patient in a psychiatric hospital or a resident in a social care home was proved by the fact that the staff of the particular facility "exercised complete and effective control by means of medication and supervision over the assessment, treatment, care, residence and movement". ${ }^{7}$

Fourthly and finally, the essence of deprivation of liberty is the imposition on the individual of an obligation to remain in a restricted space continuously, or for such a significant period of time during the day, that the effect of that obligation, because it excludes the possibility of free movement for a significant period of time, is to make it impossible or very difficult to lead a normal life. It is not possible to define with precision the minimum period of confinement necessary to qualify as a deprivation of liberty. This assessment must always be made in concreto, taking into account the nature and extent of the restriction of freedom which accompanies the obligation to stay in the particular place, in order to assess whether or not the individual has been prevented from leading a normal life. ${ }^{8}$ However, this criterion will certainly be met if the individual is required to stay in a particular place continuously.

Sometimes it will be necessary to use a fifth criterion, the consent criterion. Where, in view of the actual possibilities of exercising freedom of movement and of deciding where to stay, it is objectively possible for an individual to choose to remain in a particular place which is accessible to him or her and in which measures involving deprivation of liberty are also carried out, the deprivation of liberty exists due to the absence of an authorization (consent) to stay there or by the application of coercive measures. For example, the voluntary stay of a patient in a hospital (psychiatric or infectious) will not constitute a deprivation of liberty regime within the meaning of Article 5(1) of the ECHR.

\footnotetext{
${ }^{7}$ D.D. v. Lithuania, 2006, \146. See also Kedzior v. Poland, 2007, \57; Atudorei v. Romania, 2008, \129.

${ }^{8}$ Raimondo v. Italy, case no.: 12954/87, ECLI:CE:ECHR:1994:0222JUD001295487, \$\$ 13 and 39; De Tommaso v. Italy, case no.: 43395/09, ECLI:CE:ECHR:2017:0223JUD004339509, \$S 86 and 88.
} 
Home quarantine or home isolation as deprivation of liberty under Polish law

Taking into account the criteria discussed above, it is necessary to consider whether or not home quarantine or home isolation mandated in connection with suspected infection or contamination with the SARS-CoV-2 virus constitutes a deprivation of liberty within the meaning of Article 5(1) of the ECHR. Of course, this assessment will always depend both on the circumstances of the particular case and domestic regulations. It is not possible to make a general assessment which will be correct in every single situation of home isolation or home quarantine. The following example illustrates the legal regulations in Poland.

Firstly, according to Polish legislation, an individual may be required, by way of an administrative decision, to undergo quarantine, which may be carried out at home, or isolation under home conditions (Article 33 ust. 1 and Article 34 ust. 1 and 2 Act of 5 December 2008 on prevention and control of infections and contagious diseases in humans (Dz. U. 2020, item 1845)). These obligations are imposed by sanitary inspection authorities, and sometimes result directly from commonly biding law (for example, in the case of crossing the state border), and require seclusion in a specific place (Article 2 pkt 11a and 12 Act of 5 December 2008 on prevention and control of infections and contagious diseases in humans). Home quarantine or home isolation consists of an obligation to stay in a particular place (at home), with a statutory prohibition against leaving the place of quarantine or confinement (Article 34 ust. 4 Act of 5 December 2008 on prevention and control of infections and contagious diseases in humans). The individual is thus obliged to remain in a specific and limited space, which satisfies the first criterion for distinguishing a deprivation of liberty (the place criterion).

Secondly, a person in home quarantine or home isolation for suspected infection or infected by SARS-CoV-2 virus may be subject to coercive measures to compel the individual to remain in confinement. Because both the SARS-CoV-2 virus and the COVID-19 disease are treated under Polish law as particularly dangerous and highly contagious diseases, coercive measures may be used against a person who fails to comply with the obligation of home quarantine or home isolation (Article 36 Act of 5 December 2008 on prevention and control of infections and contagious diseases in humans). These include restraint, immobilisation or forced administration of 
medication. Restraint and immobilization are particularly important because they can effectively prevent a person from leaving the place of isolation or quarantine. Therefore, they constitute a form of coercion essential to the existence of a situation of a deprivation of liberty.

Moreover, the failure to comply with the obligation to stay in the place of home quarantine or home isolation is punishable as a petty offence (Article $116 \rrbracket 1$ Act of 20 May 1971 Code of petty offences (Dz. U. 2021, item 281). A person who does not observe the orders, prohibitions, restrictions and obligations specified in the regulations on preventing and combating infections and infectious diseases in humans, or does not observe the administrative decisions issued by the sanitary inspection authorities, commits a petty offence punishable by a fine or a reprimand. Consequently, despite the absence of "confinement", there is a legal and factual possibility of using coercion measures to force an individual to remain in a place of quarantine or isolation. Therefore, the coercion criterion is also met.

Thirdly, the legal regulations in Poland provide mechanisms to control whether or not an individual complies with home quarantine or home isolation. For example, authorized Polish authorities may impose upon an individual the legal obligation to install dedicated software on a mobile device. This software is used to verify periodically whether or not an individual is complying with the obligation to stay in the place of quarantine (Article 7e Act of 2 March 2020 on specific arrangements to prevent, counter and combat COVID-19, other communicable diseases and emergencies caused by them (Dz. U. 2020, item 1842)). Every day, on a random basis, the person in quarantine is ordered to perform tasks and to confirm the fulfilment of these tasks via mobile phone and installed software. This mobile software is used to ensure that an individual remains continuously in residence (at home). In addition, existing legislation gives the police the competence to perform the relevant activities, in order to ensure the proper implementation of the obligation of home quarantine or home isolation (Article 11d Act of 2 March 2020 on specific arrangements to prevent, counter and combat COVID-19, other communicable diseases and emergencies caused by them). The police can thus monitor whether or not individuals comply with their obligation of home quarantine or home isolation, and detain those who evade this obligation. 
Finally, the time criterion is also met, because during the whole period of home quarantine or home isolation the individual is obliged to remain in the place of confinement continuously. What is more important, this is a significant period of time because it is counted in days or weeks.

In view of the above, it must be assumed that under Polish law, home quarantine or home isolation, applied in connection with the prevention of the SARS-CoV-2 virus and COVID-19 disease pandemic, constitute examples of deprivation of liberty within the meaning of Article 5(1) of the ECHR. It should be recalled, however, that the qualification of home quarantine or home isolation as a deprivation of liberty under Polish law, and not merely a restriction on freedom of movement, does not mean that these measures will be similarly qualified under domestic law in other States. This assessment will always depend on how these measures are regulated, applied and enforced under domestic law. Sometimes these measures will constitute deprivation of liberty, particularly when their essence will be similar to the solutions currently existing in Polish legislation (Litins'ka \& Karpenko, 2020: 374-377 and 383). At other times, these measures will only be classified as a restriction on freedom of movement, especially when the individual is free to leave home (place of residence $)^{9}$.

\section{Consequences of qualifying home quarantine or home isolation as deprivation of liberty}

When home quarantine or home isolation under Polish law meets the criteria to qualify as a deprivation of liberty the State is required to satisfy various substantive and procedural conditions pursuant to Article 5 of the ECHR in order to protect the impacted individual from the arbitrary deprivation of liberty. Several noteworthy issues arising under Article 5 are discussed in the following paragraphs.

Since it is permissible to deprive persons of their liberty in a situation when there is only a suspicion that they are suffering from a contagious disease, compliance with the requirement of proportionality of the restriction of personal liberty requires that verification (diagnostic) measures should be taken without delay. The failure to carry out these measures may constitute evidence of undue restrictions of individual

9 Terheş v. Romania, case no.: 49933/20, ECLI:CE:ECHR:2021:0413DEC004993320, \ 42-45. 
freedom (Dukiet-Nagórska, 2002: 24) and thus lead to arbitrary deprivation of liberty. Consequently, in the case of home quarantine in connection with the suspicion of infection with the SARS-CoV-2 virus, the public authorities have the duty to verify, by appropriate diagnostic tests, whether or not a person has in fact been infected by that virus. This obligation should be completed as soon as possible. Depriving a person of liberty may be used as a measure of last resort in the limited situation where such person has an actual and speedy access to testing in order to verify whether or not he or she is infected by the SARS-CoV-2 virus. Home quarantine (as a deprivation of liberty) may last only as long as is necessary to achieve the goal of preventing the spread of the epidemic.

The use of preventive deprivation of liberty as a measure of counteracting an epidemic or pandemic must conform with the principle of proportionality. The State must employ the least restrictive solutions possible to achieve its objectives and which interfere as little as possible with the rights and freedoms of individuals. Accordingly, in addition to choosing the least restrictive measure, the public authority must also take steps to limit the scope and nature of interference with the rights and freedoms of individuals. If the State decides to use a solution which substantially interferes with the freedom of individuals by depriving them of their liberty, then it is incumbent on the State to act in other fields. Therefore, the primary duty of the State is to create factual mechanisms and legal solutions which make it possible to manage the risks associated with an epidemic or a pandemic in ways which do not involve the deprivation of liberty.

In the context of the COVID-19 disease or other emerging pathogens, it is essential for the State to take steps to improve its knowledge of the type and nature of the threats they pose as well as the preventive measures that are necessary to control, minimize and ultimately eliminate the threat to human life and health. Developing this knowledge is crucial in order to strike an appropriate balance between the need to protect public health while minimizing, to the extent possible, restraints on individual rights and freedoms, including both the freedom of movement and personal liberty (Meier, Evans \& Phelan, 2020: 228). However, it appears that the application of the precautionary principle from Article 168 of the Treaty on the Functioning of the European Union to threats of a general nature may justify a wider use of isolation measures when there is uncertainty about the nature and origin of the danger, in order to protect the population effectively. 
The use of home quarantine or home isolation in connection with the precautionary principle must be linked to the provision of adequate procedural safeguards in order to protect an individual against arbitrary deprivation of liberty. However, in the event of a worldwide epidemic or a new viral pandemic, the procedural guarantees linked to the assessment by the court of whether or not the measure is justified, may be problematic to implement. This is the consequence of an assessment that the methods of prevention and treatment are new and their effectiveness is not proven (Wiley, 2018: 254). Considering the risk of arbitrary or excessive restrictions of personal freedom that exists at that time, in my opinion, it is critically important to guarantee the right to a trial. This is because the proportionality of imposing a preventive measure of deprivation of liberty on a particular person always requires a balancing between the protection of personal liberty on the one hand and the common interest (public health) on the other, particularly in times of national crisis. Only an independent and impartial court should ultimately assess whether the actions taken by the public authorities correctly weighed these interests and whether, as a consequence, the deprivation of liberty of the person was arbitrary (Elias, 2016: 137).

In addition, the temptation to use large-scale home quarantine or home isolation may increase with the duration and territorial extent of the outbreak. If there is growing social unrest, including among health care workers, and existing methods of control of infection and risk management do not produce immediate results, there may be an increasing risk of using preventive detention measures against persons posing a risk to society (Coker, 1999: 1435). This intensifies the need for an independent and impartial court to assess the actions of the public authorities in order to verify the appropriateness of the State's response to the prolonged state of the epidemic (pandemic).

In cases involving the deprivation of liberty, the judicial authorities must be involved not only to ensure adequate guarantees of human rights but also respect for the principle of separation of powers. However, counteracting a nationwide epidemic threat requires either that the legislator adopt general solutions, affecting all members of society, or that public administration bodies take immediate action (Gray, 2015: 794-795). It is therefore possible, on the basis of both general and abstract rules in commonly binding law, to impose on all members of society an obligation to submit to substantial restrictions on personal freedom which may be 
referred to as "community-wide containment" (Wilder-Smith \& Freedman, 2020: 2). However, the question arises whether such a solution amounts to a deprivation of liberty within the meaning of Article 5(1) of the ECHR.

In order to satisfy the test of necessity and to be a measure of last resort, the deprivation of liberty under Article 5(1)(e) of the ECHR must be justified by the existence of a danger of the infection or contagious disease spreading, and must be established in concreto. The essence of the preventive deprivation of liberty precludes the decision to apply an isolation measure to an individual from being taken by way of a general-abstract act. This is true because in such a case there would be no assessment of the concrete factual situation in which the impacted person concerned finds himself or herself. The danger of other interests connected with that concrete situation also would not be assessed. A measure of home isolation or home quarantine is justified only if the person concerned has actually been exposed to the infection. A general suspicion that a person may be potentially infected or has been exposed to infection is not sufficient (Underhill, 2020: 65). An individual's actual (not hypothetical) physical condition cannot be ascertained without assessing that individual's particular case. Home isolation or home quarantine shall be permissible only if the public authorities prove that these are the least restrictive measures necessary to protect public health in the specific factual circumstances (Parmet, 2020). This assessment is not possible through an act of the legislator.

Consequently, it is not permissible, in the light of Article 5(1) of the ECHR and the prohibition of arbitrary deprivation of liberty, to apply isolation measures, including home quarantine or home isolation, solely on the basis of legislative acts (decisions of the legislature). The deprivation of personal liberty can only result from an act of law enforcement (e.g. administrative decision of public administration body, court decision), subject to subsequent judicial review. A similar position can be found in the jurisprudence of the Polish Constitutional Tribunal. This Tribunal has emphasized that "one of the most important elements in guaranteeing that the deprivation of an individual's liberty occurs only in particularly justified circumstances is the statutory guarantee of full, effective judicial - and therefore procedural - review of the need to deprive an individual of his liberty. This precludes the constitutional permissibility of deprivation of liberty by operation of law" (Judgment of the Constitutional Tribunal of 17 July 2013, case no.: SK 9/10, OTKA 2013/6/79). 
In my opinion, a breach of the standard of protection against arbitrary deprivation of liberty arising from Article 5(1) of the ECHR occurs in all those situations in which, by way of a decision of the legislature (on the basis of an act of lawmaking rather than an act of law enforcement), obligations are imposed either on a particular person or group of persons having certain characteristics to remain in a particular place of detention, including home quarantine or home isolation. Such a solution is not even justified by the worldwide pandemic of the SARS-CoV-2 virus.

\section{Acknowlegment}

This work is the result of the implementation of the research project No. 2015/19/D/HS5/00102 "Preventive deprivation of liberty and human rights" funded by the Polish National Science Centre.

\section{Legislation, Acts, Regulations and Court Decisions}

Akopyan v. Ukraine, case no.: 12317/06, ECLI:CE:ECHR:2014:0605JUD001231706

Amuur v. France, case no.: 19776/92, ECLI:CE:ECHR:1996:0625JUD001977692

Ashingdane v. the United Kingdom, case no.: 8225/78, ECLI:CE:ECHR:1985:0528JUD000822578

Atudorei v. Romania, case no.: 50131/08, ECLI:CE:ECHR:2014:0916JUD005013108

Buradji v. the Republic of Moldova, case no.: 23755/07, ECLI:CE:ECHR:2016:0705JUD002375507

Creangă v. Romania, case no.: 29226/03, ECLI:CE:ECHR:2012:0223JUD002922603

Dacosta Silva v. Spain, case no.: 69966/01, ECLI:CE:ECHR:2006:1102JUD006996601

D.D. v. Lithuania, case no.: 13469/06, ECLI:CE:ECHR:2012:0214JUD001346906

Delijorgii v. Albania, case no.: 6858/11, ECLI:CE:ECHR:2015:0428JUD000685811

De Tommaso v. Italy, case no.: 43395/09, ECLI:CE:ECHR:2017:0223JUD004339509

Engel and others v. the Netherlands, case no.: 5100/71, 5101/71, 5102/71, 5354/72 and 5370/72, ECLI:CE:ECHR:1976:0608JUD000510071

Enhorn v. Sweden, case no.: 56529/00, ECLI:CE:ECHR:2005:0125JUD005652900

Gillan and Quinton v. the United Kingdom, case no.: 4158/05, ECLI:CE:ECHR:2010:0112JUD000415805

Gurzardi v. Italy, case no.: 7367/76, ECLI:CE:ECHR:1980:1106JUD000736776

H.L. $v$. the United Kingdom, case no.: 45508/99, ECLI:CE:ECHR:2004:1005JUD004550899

Kedrior v. Poland, case no.: 45026/07, ECLI:CE:ECHR:2012:1016JUD004502607

Lavents v. Latvia, case no.: 58442/00, ECLI:CE:ECHR:2002:1128JUD005844200

M. v. Ukraine, case no.: 2452/04, ECLI:CE:ECHR:2012:0419JUD000245204

Mancini v. Italy, case no.: 44955/98, ECLI:CE:ECHR:2001:0802JUD004495598

Mihailovs v. Latvia, case no.: 35939/10, ECLI:CE:ECHR:2013:0122JUD003593910

Nikolova v. Bulgaria (no 2), case no.: 40896/98, ECLI:CE:ECHR:2004:0930JUD004089698

Ninescu v. the Republic of Moldova, case no.: 47306/07, ECLI:CE:ECHR:2014:0715JUD004730607

Raimondo v. Italy, case no.: 12954/87, ECLI:CE:ECHR:1994:0222JUD001295487

Shimovolos v. Russia, case no.: 30194/09, ECLI:CE:ECHR:2011:0621JUD003019409

Shtukaturov v. Russia, case no.: 44009/05, ECLI:CE:ECHR:2010:0304JUD004400905

Stanev v. Bulgaria, case no.: 36760/06, ECLI:CE:ECHR:2012:0117JUD003676006

Storck v. Germany, case no.: 61603/00, ECLI:CE:ECHR:2005:0616JUD006160300

Terhes v. Romania, case no.: 49933/20, ECLI:CE:ECHR:2021:0413DEC004993320

Vachev v. Bulgaria, case no.: 42987/98, ECLI:CE:ECHR:2004:0708JUD004298798

JE v. DE, case no.: FD06P01393, [2006] EWHC 3459 (Fam)

Judgment of the Constitutional Tribunal of 17 July 2013, case no.: SK 9/10, OTK-A 2013/6/79 


\section{References}

Ashworth, A. \& Zender L. (2014) Preventive Justice (Oxford: Oxford University Press).

Coker, R. (1999) Public health, civil liberties, and tuberculosis. How society encourages compliance reflects society's approach to the vulnerable, BMJ, 318(7196). pp. 1434-1435.

Dukiet-Nagórska, T. (2002) Uwagi na temat ustawy z dnia 6 września 2001 r. o chorobach zakaźnych i zakażeniach (Dz.U. Nr 126, poz. 1384), Prawo i Medycyna, (11).

Elias, R.A. (2016) Preventing Contagion and Protecting Civil Liberties: Problems in Quarantine \& Isolation Law in the United States \& Suggestions for Reform, Charlotte Law Review, 7(135).

Gray, A. (2015) The Australian quarantine and biosecurity legislation: Constitutionality and critique, Journal of Law and Medicine, 22(4), pp. 788-810.

Katzenmeier, C. (2020) Grundrechte in Zeiten von Corona, Medizinrecht, 38, pp. 461-465, doi: $10.1007 / \mathrm{s} 00350-020-5561-8$.

Litins'ka, Y. \& Karpenko O. (2020) Does Self-isolation Violate the Right to Liberty? An Analysis of the European Court of Human Rights' Practice in Light of the Ukrainian Experience, European Journal of Health Law, 27(4), pp. 368-385, doi: 10.1163/15718093-BJA10024.

Meier, B.M., Evans, D.P. \& Phelan, A. (2020) Rights-Based Approaches to Preventing, Detecting, and Responding to Infectious Disease, In: Eccleston-Turner M., Brassington I. (eds.) Infectious Diseases in the New Millennium. Legal and Ethical Challenges, pp. 219 and 226 (Springer).

Parmet, W.E. \& Sinha, M.S. (2020) Covid-19 - The Law and Limits of Quarantine, The New England Journal of Medicine, 382:e28, doi: 10.1056/NEJMp2004211.

Schabas, W.A. (2015) The European Convention on Human Rights. A Commentary (Oxford).

Spadaro, A. (2020) COVID-19: Testing the Limits of Human Rights, European Journal of Risk Regulation, 11(2), pp. 317-325, doi: 10.1017/err.2020.27.

Sroka, T. (2020) Ograniczenia praw i wolności konstytucyjnych oraz praw pacjenta w związku z wystapieniem zagrożenia epidemicznego, Palestra, 6.

Sroka, T. (2021) Prewencyjne pozbawienie wolności, Kraków.

Trechsel, S. (1993) Liberty and Security of Person, In: Macdonald R.St.J., Matscher F., Petzold H. (eds.)

The European System for the Protection of Human Rights (Dordrecht, Boston and London:Brill).

Underhill, K. (2020) Public Health Law Tools: A Brief Guide, In: Pistor K. (ed.) Law in the Time of COVID-19, p. 65 (Columbia Law School).

Wilder-Smith, A. \& Freedman, D.O. (2020) Isolation, quarantine, social distancing and community containment: pivotal role for old-style public health measures in the novel coronavirus $(2019-\mathrm{nCoV})$ outbreak. Journal of Travel Medicine, 27(2), pp. 1-2, doi: 10.1093/jtm/taaa020.

Wiley, L.F. (2018) Infectious Disease, In: Burger M., Gundlach J. (eds.) Climate Change, Public Health, and the Law (New York: Cambridge University Press). 